\title{
Settlers-Indigenes Question in Nigeria: Much Rhetoric, No Answers
}

\author{
Olusola E. Akintola \\ Head of Civil Service of the Federation, Federal Secretariat, Abuja, Nigeria \\ Ph.D Candidate, Department of Political Science, \\ University of Abuja, Nigeria \\ Akumka Joseph Yabayanze \\ Nigeria Customs Service, Headquarters, Abuja, Nigeria
}

doi: 10.19044/esj.2017.v13n10p365 URL:http://dx.doi.org/10.19044/esj.2017.v13n10p365

\begin{abstract}
Nigeria operates a federal system of government whereby Nigerians can reside in any part of the country and enjoy the rights and privileges of being the citizens of the country. However, the experiences of the citizens across the states of the federation have proved that this ideal is not true in all instances. The authors, therefore, examined settlers-indigenes question in Nigeria placing the theoretical citizenship as contained in the 1999 Constitution (as amended) side-by-side with the reality of the country. Secondary source of data collection was adopted as our methodology. Through this method, explanatory and deductive analysis was made. The findings of the paper revealed that settlers-indigenes question is negatively affecting Nigerian federalism and the peaceful co-existence of citizens. It was, therefore, recommended that Section 147 of the 1999 Constitution (as amended) which encourages indigeneship should be expunged or amended as it reinforces division and heightens settlers-indigenes question in the country.
\end{abstract}

Keywords: Nigerian federalism, settlers-indigenes, 1999 Constitution (as amended), citizenship

\section{INTRODUCTION}

As a political system, Nigeria is unique and exceptionally different from other countries. For instance, although Nigeria operates a federalpresidential-democracy like the United States of America (USA), the theory and practice of the system in Nigeria is unique. This is not because the Nigeria's constitution is so much different in theory regarding what is obtainable in the Constitution of the USA, but in practice. Nigeria's federal- 
democracy is out of the blue. The chief among the strange thing about Nigerian federalism is the 'definition' of who is a Nigerian. Everyone born in the country is practically a citizen of the country, but not everyone given birth to in a state (the second tier of government in Nigerian federation) is truly regarded as a bonafide Nigerian in that state. This gives birth to settlerindigene lexicon in the political vocabulary of Nigeria. Thus, settlersindigenes question has been one of the greatest challenges confronting Nigerian federalism.

Complicating settlers-indigenes question in the country is seen in the 1999 Constitution (as amended) of the Federal Republic of Nigeria. The Constitution frowns at discrimination, yet it upholds indigeneship. By implication, the Constitution encourages unity - one Nigeria - and paradoxically, it encourages the disintegration of the country.

The focus of this paper, therefore, is to examine the issues relating to settlers-indigene question in Nigeria. The focus of the authors is to analyse how the movement of people across the geo-political zones and ethnic divides (in history and at present) has not only affected the practice of federalism in Nigeria, but also have a significant impact on the political development of the country. The paper is divided into five parts after this introduction. The theoretical analysis comes after the introduction; the next section focuses on the genesis of settlers-indigenes brouhaha in Nigeria. This is followed by looking at how the 1999 Constitution (as amended) has complicated settlers-indigenes question in Nigeria. The fourth part examines various ways of achieving 'true Nigerianness', suggesting what should be done. The final part of the paper is the conclusion.

\section{Theoretical Analysis}

The elite theory was adopted as the theoretical basis of the analysis of this paper. This theory was advanced in the early twentieth century by three famous sociologists: Vilfredo Pareto, Gaetano Mosca, and Robert Michels. According to Gauba (2003:258), the term 'elite' as a category of sociological analysis was introduced by Pareto, while the idea associated with the theory was floated earlier by Mosca. The term 'elite' was derived from French where it meant to be something excellent (Gauba, 2003:258). Pareto, in his book titled “The Mind and Society" (1915-19), used the term to indicate a group of people who show the highest ability in their field of activity whatever its nature might be. However, to Mosca in his work titled "The Ruling Class” (1896), the people (the society or a political system) are divided into two groups: the rulers and the ruled (Gauba, 2003:259). The rulers are the elite and they control most of the wealth, power, and prestige in the society. The ruled are referred to as the masses and are said not to be able to replace the elite. 
It is worthy to note is the fact that classical elitists make use of the inevitability of elite rule as a premise to counter argue with political liberalism and Marxism. Lopez (2013:2) stated that classical elitists claimed that both democracy (as the government of the people or demos) and socialism (as a classless regime) were impossible outcomes because society is necessarily elite driven. These theorists believe that elites could only be substituted by another set of elites. However, this means that the majority is necessarily ruled by a minority. This notion was expressed in Pareto's (1935) law of elite circulation and in Mosca's (1939) notion of political class.

According to Lopez (2013), the principle or law of elite circulation holds that elites alternate in power as a result of either peaceful or violent competition. In Pareto's (1935) terms, history is (and could only be) nothing but a 'cemetery of elites' (cited in Lopez, 2013:2). The notion of political class, which is currently less frequent in elite studies, defines elites as a class of political rulers- in opposition to a mass of followers.

Furthermore, in the classical elitist literature, elites were often (but not only) defined through capacity, personality, and skill. It was submitted, for instance, that Pareto (1935) distinguished elites between those who resembled the lion (domination by force) and those who resembled the fox (domination by persuasion and skill). Therefore, it was a typology that resembles Machiavelli's political philosophy. Mosca (1939) made mention of material conditions and the intellectual and moral superiority of elites (Lopez, 2013:2-3).

In its classical formulation, elite theory seeks to describe and explain the power relationships in contemporary society. The theory posits that the minority, consisting of members of the economic elite and policy-planning networks, holds the most of the power. This power is independent of the state democratic electoral process. Elite theory was developed as an alternative paradigm to pluralism. It rejects the pluralist view concerning the distribution of power in society. Mosca argued that a minority group, as against the pluralist perspective, performs all political functions, monopolizes power, and enjoys the advantages that power brings (cited in Sambo, 1999:293). As a minority group within the society, the elite have many manipulative devices they use against the masses, the majority. They use manipulative skills, including oratory, persuasion, and playing upon the sentiments of the people to perpetuate themselves into power (according to Robert Michels in his 'Iron Law of Oligarchy', Gauba, 2003:259). Consequently, power is concentrated in the hands of the few. These few, therefore:

Occupy the strategic command posts within the social structure. Power elites constitute a selfconscious class whose members help each 
other on the basis of mutual understanding, tolerance and cooperation in order to strengthen each other's power and position (Gauba, 2003:261).

Based on the argument of the elite theorists, settler-indigene dichotomy in Nigeria is actually the manifestation of the manipulative skills of the elites in the country. The dichotomy itself is an objective reality that could be managed for political development in Nigeria. Nevertheless, this is used but for the playing upon the sentiments of the Nigerian masses, especially the one attached to ethnicity. Settler-indigene issue, therefore, has become one of the national questions that are difficult to manage in the country. The Nigerian political elite are doing this in order to perpetuate themselves in power and keep the masses, the Nigerian citizens, divided against each other instead of being united against the parasitic elites.

Since Nigerian political elites have been "sentimental, uncontrollably dependant (sic), greedy or materialistic, and in most cases non-nationalistic" (Azeez and Ibukunoluwa, 2015:155), they have become self-centred. Thus, they are only concerned about their welfare and that of their immediate families. As against "elite consensus" (Lopez, 2013:5) that guarantees democratic consolidation, the attitude of the Nigerian elites reinforces 'no permanent enemy (in politics) but permanent interest'. The interest is, however, not that of the corporate development of Nigeria but that of the individual elites. They, therefore, use settlers-indigenes dichotomy among Nigerians to achieve their permanent interest, which is to remain relevant in politics and perpetually occupy political posts.

\section{THE GENESIS OF SETTLERS-INDIGENES BROUHAHA IN NIGERIA}

The beginning of what is today known as Nigeria is traceable to many communities and ethnic groups existing in the pre-colonial era. Apart from other 'smaller' socio-ethnic kingdoms, three major political organisations existed in the pre-colonial times; the Old Oyo Empire in what is referred to as the South-West (Yoruba) today, the Sokoto Caliphate (in today's Northern part of Nigeria), and the village political structure of the Igbo society (South Eastern part of the country). Each of these major political organisations in the pre-colonial times existed independent of each other and were organised based on the peculiarities and needs of the people.

In broad terms, the people of "Nigeria" in the pre-colonial era were organised into either centralised or non-centralised systems of government. The formal system usually had kings, class arrangement, administrative officials, privileges of ranks, regulation of tax and tributes, among others. The latter does not possess these features in clear-cut manner (Dauda, 
2012:2). It is these political arrangements that the colonial master, the British Imperial Government, met on ground when the Nigerian area was subjugated. The colonial government initially created Southern and Northern Protectorates, ruling them separately, before the two Protectorates were amalgamated in 1914.

Furthermore, the bringing together of the two Protectorates can be seen as the genesis of federalism in Nigeria. Sadly, the genesis of settlersindigenes question is traceable to this amalgamation. Federalism, according to Babalola (2013:43), in Nigeria was necessitated by the desire to achieve 'unity in diversity'. However, from the outset, the British Imperial Power had another agenda. It was a "divide and rule" (Nnoli, 2003:3) strategy employed by the colonial state to heighten "ethnic and regional sectionalism (in order) to curb Nigerian nationalism and to maintain colonial power (Nnoli, 2003:3)". In fact:

The colonial state seized every available opportunity to spread the propaganda that Nigerians did not have a common destiny... because they were separated by differences of history and tradition. Its policy was to secure the right of each ethnic group to maintain its identity, individuality, nationality and chosen form of government, and the peculiar political and social institutions that were presumed to have evolved from the wisdom and accumulated experiences of its previous generations (Nnoli, 1978: 120-122).

Therefore, instead of achieving unity in diversity (as Babalola argued), the various ethnic groups are pulled apart through the heightened consciousness of their differences rather than features that bring them together. Since then, till independence and up till today, ethnicity, the feeling of marginalization and discrimination, political exclusion and exploitation among the Nigerian citizens across all states of federation had been unresolved issues in Nigerian federalism. These ugly trends have manifested in different ways in the country.

Chief among the manifestations of heightened differences among Nigerians as they live across states in the federation is ethno-political crisis. Both settlers and indigenes in the states struggle for political relevance and rights. Therefore, this has led to armed conflict and political crises. Postindependence Nigeria has witnessed political crises like the 1951 Western Region House of Assembly election crisis in which the "National Council of Nigerian Citizens (NCNC) defeated the Action Group (AG) in the Western Region. The NCNC won 35 seats, while the AG secured 29 seats. The AG was created as a Yoruba political party with Western Region as its base. Thus, it was defeated by the NCNC, which was considered an Igbo and 
Eastern Region party (Abba, 2005:10). This led to the crisis in the Western region. Also, the 1954 federal election crisis, 1964 federal election crisis, 1979 federal election crisis, and even the June 12, 1993 crisis could be traced to the scramble for power, political space, and relevance occasioned by the abnormality identified with the Nigerian federalism.

In the Fourth Republic, this ugly trend has led to killings of innocent Nigerians across the states of the federation. In the timeline of ethnopolitical crises provided by Saheed and Egwaikhide (2012:178-179), one realises that settlers-indigenes question is more heightened as democracy was re-institutionalised in Nigeria in May 1999. Among the crises experienced based on settlers-indigenes dichotomy are:

i. $\quad$ May 30 - June 9, 1999: renewed Warri communal clash in Delta State.

ii. July 18, 1999: Oodua People's Congress and Hausa traders clashed in Sagamu, Ogun State.

iii. November 25, 1999: communal clash in Lagos between Oodua People ${ }^{\text {ee }}$ Congress and Hausa traders.

iv. January 25, 2000: communal clash in Brass Local Government Area, Balyesa State.

V. January 29-30, 2000: communal clash in Etsako West Local Government Area, Edo State.

vi. February 2, 2000: boundary dispute between communities in Akwa Ibom and Cross Rivers State.

vii. March 16, 2000: renewed hostilities between the people of Eleme and Okirika in Rivers State.

viii. April 8, 2000: communal clash in Ovia South Local Government, Edo State.

ix. May 18, 2000: clash between local farmers and Fulani cattle rearers in Saki, Oyo State.

X. June 5, 2000: epoch of the Owo mayhem in Ondo State.

xi. June 12, 2000: communal clash between the people of Ikot Offiong and Oku-Iboku of Cross Rivers State.

xii. July 1, 2000: communal clash in Ikare Akoko, Ondo State.

xiii. July 21, 2000: renewed hostility between the Ijaws and Urhobos in Delta State.

xiv. August 12, 2000: communal clash in Bende Local Government Area of Abia State.

XV. October 16, 2000: clash between Igbos and Hausa traders at Alaba Rago market, Lagos State. 
Xvi. December 11, 2000: renewed clashes between Ife and Modakeke in Osun State.

Xvii. March 13, 2001: renewed communal clashes in Owo, Ondo State.

Xviii. May 12, 2001: communal clash between Odimodu and Ogulagba communities in Delta State.

xix. July 12, 2001: ethnic violence in Nasarawa State.

XX. February 2, 2002: Oodua People’s Congress and Hausa people clashed at Idi Araba, Lagos State.

xxi. February 26, 2002: communal clash between Apprapum and Osatura communities in Cross Rivers State.

xxii. March 10, 2002: ebira youths revolt on local government creation.

xxiii. March 30 - April 2, 2002: All Peoples Party intra party clash in Ilorin, Kwara State.

xxiv. August 31, 2002: communal clash in Ado Ekiti.

XXV. September 3, 2002: renewed communal clashes in Owo, Ondo State.

Furthermore, among the devastating attacks by the Fulani herdsmen were those experienced in Benue, Plateau, Kaduna, Niger, Jigawa, Sokoto, Edo, Delta, Yobe, and Anambra States. The Fulani herdsmen usually set houses on fire, sack communities, and occupy them. Thus, this presents a special form of movement of people in Nigeria because:

The conflict between the Fulani herdsmen and the farmers usually arise when the former invade community farmland with their cattle and let them graze unrestricted both on cultivated and uncultivated land thereby destroying valuable food and cash crops which are the mainstay of the host communities (Daily Independent, Editorial; Saturday, July 12, 2014).

The herdsmen do not tolerate co-existence but extinction of the host community. "Their hosts, who ordinarily should be their friends for accommodating them, are slaughtered with reckless abandon” (Kumolu, 2014:1). This goes to prove that even with the dawn of democracy in Nigeria and with the 1999 Federal Constitution (as amended), the settlers-indigenes question is still prevalent in the operation of the country's federal system of government. However, in what specific ways does the 1999 Constitution (as amended) lack the power to solve settlers-indigenes problem in Nigeria? To this, the study now turns. 


\section{CONSTITUTION (AS AMENDED) AND THE SETTLERS- INDIGENES QUESTION}

Ideally, a constitution, which serves as a basic institutional framework of government, is supposed to define the relations between rulers and the ruled, the rights and duties of citizens, and many important procedures are to be followed in connection with those matters in which all are carefully set out (Anifowose, 1999:157). However, as if the challenges Nigeria has with settlers-indigenes dichotomy were not enough, the promulgation of the 1999 Constitution (as amended) makes the issue worse.

The definition of a Nigerian is clearly spelt out in the 1999 Constitution, but the clarification on an indigene and a settler is still a bone of contention. The citizenship of Nigeria can be acquired by birth, by registration, and by naturalisation (Sections 25, 26 and 27 of the 1999 Constitution, as amended). Consequently, as a citizen of Nigeria, every Nigerian has a right to freedom from discrimination. In Section 42, Subsections 1 and 2, it is stipulated unequivocally that a citizen of a particular community, ethnic group, place of origin, sex, religion or political opinion shall not, by any reason only that he is such a person -

a. be subjected either expressly by, or in the practical application of, any law in force in Nigeria or any executive or administrative action of the government, to disabilities or restrictions to which citizen of Nigeria of other communities, ethnic groups, places of origin, sex, religions or political opinions are not made subject; or

b. be accorded either expressly by, or in the practical application of, any law in force in Nigeria or any executive or administrative action any privilege or advantage that is not accorded to citizen of Nigeria of other communities, ethnic groups, places of origin, sex, religions or political opinions.

2. No citizen of Nigeria shall be subjected to any disability or derivation merely by reason of the circumstances of his birth.

In essence, the Constitution does not accord any special privileges to any Nigerian living in any part of the country. Also, it does not allow any Nigerian to be discriminated against because the individual comes from a specific part of the country. This therefore means, according to Omotoso (2014:7), that a Nigerian regardless of where he lives is a citizen of the country as long as the parents or grandparents are Nigerians. Apart from this, as a citizen of the country, such individual is free to live and work anywhere in the Federal Republic of Nigeria. In practical terms, this is not the situation in the country. This will be discussed later in this study.

Unfortunately, the Constitution recognises, by implication, an indigene in a state of the federation. Being an indigene of a state in the country is one of the main criteria to be appointed as a Minister of the 
Government of the Federation. In Section 147, Subsection 3 of the Constitution, it is stated that "the President shall appoint at least one Minister from each State, who shall be an indigene of such State" (emphasis authors'). However, there is no mention of anything like settlers in the whole document. With this, it is glaringly clear that Nigerian federalism recognises indigeneship at the state level but citizenship at the federal level. This has been one of the banes of Nigerian federalism.

In reality, whether it is spelt out in the constitution or not, the happenings in Nigeria have made the settlers-indigenes question a burning issue in the country. The supporters of the dichotomy between indigenes and settlers would easily contend that one is mostly an indigene of a particular place. The argument is that one can only belong to a particular ethnic group and by virtue of that, one might not be in a position to enjoy those benefits associated with settling in a place or among groups with different history, tradition, and language (Adesoji \& Alao, 2009:153). Pushing the dichotomy further is the argument of Rinyom (2011) that:

Whereas indigeneship is a natural link between a person and a geographical location - his ancestral home - where he traces his roots through a blood lineage and genealogy that puts him in contact with his kin and kindred, citizenship (herein referred to a Nigerian in another state) is a man-made arrangement that seeks to confer on a person in a certain geographical location (an ownership of the place).

In most cases, this is how Nigerian citizens from different states perceive those who have no ethnic origin in the state of their settlement. However, as the so-called "settlers" live in a particular state for a long time, defining their indigeneship becomes blurred. An example is given of one Alhaji Ismail Babatunde Jose. In his x-ray of the genealogy of the man (Alhaji Ismail Babatunde Jose), Oyeweso (2006:30-31 cited in Adesoji and Alao, 2009:153) contends that the idea of ethnic purity is neither illogical nor impracticable. Jose's genealogy is first traced to Ikare-Akoko, where his great grandfather was born and later to Ijebu-ode where his grandfather got married to a royal family. His genealogy was also traced to Sokoto and Bida, the roots of her great grandmother and grandmother respectively and finally Lagos where Ismail was born. Also his grandfather residency at Calabar where Hamza Jose, his father, was born was also considered relevant. Therefore, some pertinent questions raised here are; Is Alhaji Jose an indigene or a settler of Lagos? Does he have a right or legitimate claim to Owa-Ale Chieftaincy in Ikare? Can he embrace or will he be embraced by the royal household of Ijebu Ode? Can or should he be discriminated against by the Nupe or Fulani based on fixed and unchanging notions of ethnic 
identity or indigeneity? Arguably, the meaning one could make out of this development is the fact that there could be multiple indigeneship (Adesoji \& Alao, 2009:153). Therefore, the best would have been to emphasise Nigeria but not indigeneship or settlers syndrome.

On the contrary, settlers-indigenes dichotomy has limited Nigerians who are living in states different from where they trace their ancestral home. They have access to social good such as education, employment opportunities, land, and political right to produce representatives or the chief or head of a community. The Jukun-Tiv scenario in present day Taraba State gives a vivid picture of this.

\section{The Jukun-Tiv Example}

Jukun and Tivs constitute the population of Wukari Local Government in Taraba State. They had been living peacefully together since the pre-colonial days with the Tiv (the migrants to Wukari areas). They are predominantly rural farmers who did not interfere with Jukun (who traced their ancestral origin to Wukari) administration. Although the Tiv had arrived in the region far back as the 1840s when the present Wukari was established (Best et al., 1999:82), political and social relations began to change for the worse in the early Twentieth Century.

The advanced reasons for the change in relations between these two ethnic groups are the introduction of party politics and the increase in the population of the Tiv (Agaba \& Akintola, 2012:15). In fact, in the 1940s, the Tiv were not only the largest ethnic group in the Middle Belt, but they were also three times more numerous than the Jukun in the Wukari Division, which the Jukun considered as their homes (Agaba \& Akintola, 2012:15). Consequently, the Jukun started to impose their political supremacy; this was the beginning of settlers-indigene dichotomy in Taraba State.

Despite all the efforts made by the colonial government to recognise the Tiv as part of the society where they lived, the Jukun essentially saw them as settlers. More importantly, the political reversals suffered by the Jukun at different times not only woke them up from their slumber; they also became more rigid in refusing or denying the Tiv access, relevance, entitlements, political participation and power on the ground that they were settlers (Best et al., 1999:82-115). Therefore, this has led to violent clashes in Taraba State. Examples of these ethno-political crises include Tiv riot of 1959-60, the 1964 'head breaking', the 1979-83 fracas, the local government election crisis of 1987, 1990-92 local government election crisis, the 20012002 clash, and August 2010 riot (Agaba \& Akintola, 2012:15-16). The bone of contention has always been on rights or privileges only meant for those who can trace their ancestral origin to Wukari. The statement credited to the paramount ruler of Wukari, Dr Shekarau Angyu Masa-Ibi Kuvyo II, 
represents the sentiment of almost every Jukun man and woman. He stated, during the 2001-2002 Jukun-Tiv Clash that:

They (the Tiv) came here to farm; we (the Jukun) allowed them, gave them chieftaincy titles...Now that their population has increased, they believe they are many enough to colonise us (cited in Asuni, 1990).

The Tiv, like many settler groups in different parts of the country, have consistently maintained that having settled in a place for a long period is not proper to refer to them as settlers, but rather as indigenes. Their contention is that while their kiths and kins could be located elsewhere, they could not really trace their root appropriately neither could they fit properly into the old society they or their forbears left several years ago (Adesoji \& Alao, 2009:154). 'True' federalism can be referred to a situation in which all Nigerians, regardless of where he/she traces his /her ancestral origin to, will be able to enjoy every social good available without discrimination as enshrined in the 1999 Constitution (as amended).

\section{TOWARDS TRUE NIGERIANNESS}

In Nigeria, the problem is not actually with the Nigerian people, but with the political elite. While it is true that settlers-indigenes question is a reality in Nigerian federal system, the political elite manipulate it for selfish political ambition. Most especially, they employ ethnicity to achieve their aim. This is what Nnoli (2003:21) alluded to when he argues that the problem is not the cultural differences among the various ethnic groups in Nigeria. In addition, it is neither their geographical differences, nor their social and economic differences. The difference among the various ethnic groups in Nigeria ethnic question arises from the degree to which this emergent identity has been manipulated. This is why a Nigerian should be redefined.

The first thing that needs to be done is to amend Section 147 of the 1999 Constitution (as amended) which encourages indigeneship. This should be expunged from the Constitution. It is an irony for a Constitution to discourage discrimination against an individual, but still encourage elements that strengthen discrimination. This is a lacuna too many in strengthening federalism in Nigeria.

As a matter of urgency, it should be purposely included in the next amendment to the Constitution that all Nigerians are eligible to enjoy every rights and privileges in every part of the country, no matter where they trace their ancestral origin to. However, this would solve two major problems in Nigeria; ethnicity and settlers-indigenes dichotomy.

Settlers-indigenes question could be solved when meritocracy becomes the only criteria for the appointment of political posts and 
employment in the country. Quota system and Federal Character, though they have their merits based on the wisdom of their proponents, are part of the elements in Nigerian federation that pull Nigerians apart. Instead of using these, every Nigerian should be given equal opportunity to serve and enjoy the rights of being a Nigerian. Lagos State is a good example on this. The present Governor of Osun State, Rauf Aregbesola, has been a Commissioner in Lagos State. On the contrary, settlers-indigenes brouhaha would have denied the former Minister of Aviation, Stella Oduah, the opportunity of being a Minister of the Federal Republic of Nigeria. This was despite her qualifications and experience. Emphasis should be on 'what you can offer' not 'where you come from' or 'who you know.'

Furthermore, there is a need to enlighten Nigerians about elite manipulation. The National Orientation Agency (NOA) has a lot to do in this regard. The Agency should begin to educate Nigerians on things that unite them and sensitise them about the essence of unity in the country. Nigerians should be informed about political elites' manipulation of ethnic differences for self-centred political ambition.

\section{CONCLUSION}

Movement of people, both now and in history, is the basis on which people come in contact with others. As a result of the contact, interactions follow. As the interactions continue, there is bound to be conflict. The issue is not the conflict but its management. Consequently, the ineffective management of conflict arising from interactions of the Nigerian people across all the states of the federation has heightened settlers-indigenes question.

The experience in Taraba State between the Jukun and the Tiv proves the fact that difference in ancestral origin and history are not the main problem in the State, but the manipulations of these issues by the Nigerian political elite. They use the issue of settler-indigene to divide the people for their political benefits. Settler-indigene question in Nigeria is the manifestation of the manipulative skills of the elites in the country.

Consequent upon the above, the Nigerian federalism would be better when Section 147 is appropriately amended. The Section needs to deemphasise the state of origin as the main criterion for national assignment as a minister. This emphasises "statehood" rather than the nationhood of Nigeria. Merit is the only way through which this can be done away with. No matter the state of origin, ministerial appointment and any other national assignment should be given based on qualifications, achievements, and past records of the would-be minister.

This is why the NOA is very strategic in nation building in Nigeria. The agency needs to justify its existence as the platform on which national 
re-orientation is done. It needs to embark on national campaigns on strength imbedded in diversity. This shows that ethnic difference is never the problem but its usage for political reasons. In this, Nigeria's unity and national integration depends.

It is noteworthy, therefore, that it is not the movement of people across ethnic or national boundaries that is the problem, but the management of conflict that might arise as a result of this movement. This is because the movement would definitely affect the socio-political equation of the environment where people settle. The relations between the Jukun and the Tiv reinforce this argument. It is for this reason that the authors submit that this needs some strategies which could help resolve the conflict (settlerindigene dichotomy). The proposed strategies would not only enhance true federalism in the country, it will also help resolve the conflict that might arise as a result of the movement of people and interactions among them.

\section{References:}

1. Abba, A. (2005). The Misrepresentation of Nigeria by Nigerians and Others. A Paper Presented at a Workshop Organised by CEDDERT on behalf of the Nigeria UN Reform Committee, Assembly Hall, ABU, Zaria, Saturday, $11^{\text {th }}$ June 2005.

2. Adesoji, A. O. and Alao, A. (2009). Indigeneship and Citizenship in Nigeria: Myth and Reality. Journal of Pan African Studies, 2(9):151-165

3. Agaba, H. and Akintola, O. E. (2012). Citizen-indigeneship Issues and Political and Socio-Economic Development in Nigeria: A Case Study of Ife- Modakeke and Tiv-Jukun Crisis. Journal of Legislative Studies and Governance, 1(3):9-22.

4. Anifowose, R. (1999). Constitution and Constitutionalism. In Anifowose, R. and Enemuo, F. (eds); Elements of Politics. Lagos: Sam Iroanusi Publications.

5. Asuni, J. B. (1999). Nigeria: The Tiv-Jukun Conflict in Wukari, Taraba State. Boulder: University of Colorado.

6. Azeez, A. and Ibukunoluwa, A. (2015). Elite Theory and Elite Circulation in Nigerian Politics. International Journal of Banking, Finance, Management \& Development Studies, 3(1): 151-161.

7. Babalola, D. (2013). The Origins of Nigerian Federalism: The Rikerian Theory and Beyond. Federal Governance, 8(3):43-54.

8. Best, S. G., Idyorough, A. E. and Shehu, Z. B. (1999). Communal Conflict and the Possibilities of Conflict Resolution in Nigeria. A Case Study of the Tiv-Jukun Conflicts in Wukari Local Government Area, Taraba State. Otite, O. and Albert, I. O. (eds.) Community 
Conflicts in Nigeria: Management, Resolution and Transformation. Ibadan: Spectrum.

9. Daily Independent Editorial (Saturday, July 12, 2014). Challenge of Fulani Herdsmen. Retrieved from http://dailyindependentnig.com/2014/03/challenge-of-fulaniherdsmen/; accessed $15^{\text {th }}$ April, 2016.

10. Dauda, S. (2012). Politics and Government in Africa. Ibadan: Daily Graphics Nigeria Ltd.

11. Federal Republic of Nigeria: 1999 Constitution (as amended) of the Federal Republic of Nigeria. Lagos: Federal Government Printer.

12. Gauba, O.P. (2003). An Introduction to Political Theory (Fourth Edition). Delhi: Macmillan India Ltd.

13. Kumolu, C. (2014). Fulani Herdsmen, Farmers Clashes: Furore over Grazing Reserves. Vanguard Newspaper, April 09, 2014; retrieved from http://www.vanguardngr.com/2014/04/fulani-herdsmen farmersclashes-furore-grazing-reserves/; accessed $23^{\text {rd }}$ May, 2016.

14. Lopez, M. (2013). Elite Theory. Sociopedia.isa, retrieved from http://www.sagepub.net/isa/resources/pdf/Elitetheory.pdf; accessed $7^{\text {th }}$ April, 2017.

15. Nnoli, O. (1978). Ethnic Politics in Nigeria. Enugu: Fourth Dimension.

16. Nnoli, O. (2003). Ethnic Violence in Nigeria: A Historical Perspective. $\quad$ Retrieved from www.indiana.edu/ workshop/papers/nnoli_021003.pdf; accessed $23^{\text {rd }}$ May, 2016.

17. Omotoso, F. (2014). Settlers and Indigenes Phenomenon in Nigerian Federalism: An Assessment of Jos, Plateau State. Retrieved from http://www.google.com/settlers-and-indegenes-phenomenon-in-nigeria-anassessement-of-jos-plateau-state/pdf; accessed $15^{\text {th }}$ April, 2016.

18. Rinyom, J. D. (2011). Indigeneship, Citizenship and the Lost Nigerianship: An Unpopular Essay (Part 1) Retrieved from http://www.gamji.com/article3000/NEWS3804.htm; accessed $15^{\text {th }}$ April, 2016.

19. Saheed, Z. S. and Egwaikhide, C. I. (2012). Impact of Social Crises on Economic Development: Theoretical Evidence from Nigeria. American International Journal of Contemporary Research, 2(6):176-184.

20. Sambo, A. (1999). What is Public Policy? In Anifowose, R. \& Enemuo, F. (eds.), Elements of Politics (281-310). Lagos: Sam Iroanusi Publications. 